\title{
POŠTA
}

TELEKOMUNIKÁCIE A

ELEKTRONICKY OBCHOD

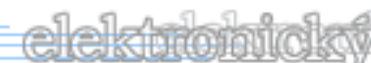

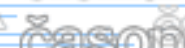

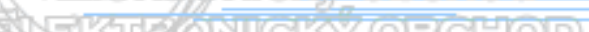

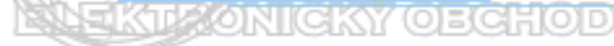

\section{PRODUKČNÁ FUNKCIA Z HLADISKA VYBRANÉHO SIEŤOVÉHO ODVETVIA}

\author{
Milan Garbier ${ }^{1}$, Tatiana Čorejová ${ }^{2}$
}

\begin{abstract}
Network industries are strategically important areas of the economy. The commodities supplied in this market are related to the basic living needs of the population. The aim of the paper is to identify the framework of production possibilities in the selected network industry. Very specific conditions and a longer history among these sectors have the heating industry, which is undergoing fundamental changes in its business model by applying new technologies.
\end{abstract}

Keywords: network industry, heating industry, production function, pricing

Úvod

Oblasti podnikania, ktoré sú súčast'ou siet’ových odvetví, v ktorých prirodzené monopoly vznikajú sú strategicky dôležitými oblast’ami hospodárstva. Komodity dodávané na tomto trhu súvisia so základnými životnými potrebami obyvatel'stva. Kontinuálne a kvalitatívne vyrovnané realizovanie dodávky energií je jedným zo základných predpokladov fungovania ekonomiky a naplnenie základných potrieb spoločnosti. Existencia dominantných subjektov monopolného charakteru ustanovuje vzájomné prístupy v rámci siet'ových odvetví medzi výrobcami, distribútormi, dodávatel'mi a ich odberatel'mi. Vzájomné fungovanie a správanie monopolných subjektov energetiky ma priamy dopad na obyvatel'stvo a jeho životnú úroveň čím ovplyvňuje aj hospodárstvo krajiny [1,2].

Ciel'om príspevku je identifikovat' rámec produkčných možností vo vybranom siet’ovom odvetví. Vel'mi špecifické podmienky i dlhšiu históriu medzi týmito odvetviami má teplárenstvo, ktoré uplatňovaním nových technológií v biznis modeli prechádza zásadnými zmenami. Regulácia v odvetví už pritom v súčasnosti nespočíva len v regulovaní cien, ale sústred’uje sa na environmentálne a sociálne aspekty.

\section{Teoretické východiská}

Teória hraničnej produktivity výrobných faktorov a teória hraničnej užitočnosti je podstatnou čast'ou a základom v neoklasickej ekonómie. J.B. Clark (1899) v diele Rozdel'ovanie bohatstva vysvetlil a rozvinul teóriu hraničnej produktivity výrobných faktorov. Podl’a teórie, každý vlastník výrobného faktora získa taký podiel produktu, ktorý vytvoril jemu prislúchajúci výrobný faktor. Teória hraničnej produktivity rieši kombináciu množstva výrobných faktorov podiel'ajúcich sa na tvorbe optimálneho množstva produktu $[1,3]$.

\footnotetext{
${ }^{1}$ Ing. Milan Garbier, externý doktorand, Katedra spojov, Fakulta prevádzky a ekonomiky dopravy a spojov, Žilinská univerzita v Žiline, Univerzitná 8215/1, 01026 Žilina, e-mail: xxx.xxxxxxx@xxx.xxx.xx

${ }^{2}$ dr.h.c. prof. Ing. Tatiana Čorejová, PhD., Katedra spojov, Fakulta prevádzky a ekonomiky dopravy a spojov, Žilinská univerzita v Žiline, Univerzitná 8215/1, 01026 Žilina, e-mail: Tatiana.corejova@,fpedas.uniza.sk
} 
Pri tvorbe produktu firmy - výstupu je spotrebúvaný materiál, energia a práca, ktoré sú jeho inputom. Vzájomnou kombináciou použitých vstupov môžu byt' dosahované rôzne vel'kosti výstupov. V takomto prípade je pre firmu podstatné zistit', aká kombinácia výrobných faktorov vyprodukuje požadované množstvo výstupu. Pre jej stanovenie je používaná analýza produkčnej funkcie. Všeobecný tvar produkčnej funkcie možno uviest' nasledovne:

$$
\mathrm{Q}=f\left(\mathrm{~F}_{1}, \mathrm{~F}_{2}, \ldots . \mathrm{F}_{\mathrm{n}}\right)
$$

kde:

Q je objem produkcie, výstup alebo output firmy

$\mathrm{F}_{1}, \mathrm{~F}_{2}, \ldots \mathrm{F}_{\mathrm{n}}$ sú použité výrobné faktory, vstupy alebo input firmy $[1,2]$

Produkčná funkcia vyjadruje vzt'ah medzi použitým množstvom imputov pre výrobu a množstvom vyprodukovaných outputov. Najjednoduchší spôsobom pre vyjadrenie vzájomného vzt’ahu medzi inputom a outputom firmy je použitie vstupov ako sú práca (L) a kapitál $(\mathrm{K}) \mathrm{v}$ podobe

$$
\mathrm{Q}=f(\mathrm{~L}, \mathrm{~K})
$$

Najčastejšie uvádzanou dvojfaktorovou substitučnou produkčnou funkciou je CobbDouglasova produkčná funkcia:

$$
\mathrm{Q}=\mathrm{A} \times \mathrm{L}^{\alpha} \times \mathrm{K}^{\beta}
$$

kde:

$\alpha$ - je koeficient elasticity objemu produkcie na zmenu L, kde sa vyjadruje relatívny prínos výrobného faktoru práce $\mathrm{k}$ celkovému výstupu,

$\beta$ - koeficient elasticity objemu produkcie na zmenu $\mathrm{K}$, ktorá vyjadruje relatívny prínos výrobného faktoru kapitálu k celkovému outputu,

A - konštanta, pričom platí, že $\alpha+\beta=1$

Lisý [1] analýzu produkčnej funkcie rozkladá do dvoch etáp, kde v prvej etape predpokladá, že spomedzi dvoch výrobných faktorov, ktoré firma využíva bude jeden fixný a druhý variabilný. Fixný faktor je kapitál a variabilná práca, kde analýza produkčnej funkcie je v krátkom období. Produkčná funkcia v krátkom období bude mat' tvar $\mathrm{Q}=f(\mathrm{~L}, \mathrm{~K}), \mathrm{kde} \mathrm{L}$ je variabilná zložka a K je fixná zložka.

Optimálna hodnota produkčnej funkcie je závislá od množstva použitých výrobných faktorov (vstupov) a spôsobu ich kombinácie, čím prinesú rozdielne výstupy

V odvetví tepelnej energetiky nemôžeme hovorit' o funkčnom konkurenčnom prostredí. Predaj tepla alebo dodávka elektrickej energie je poskytovaná práve prirodzene monopolným subjektom alebo malým počtom silných subjektov. Táto situácia na trhu vzniká prirodzene vybudovaním a vlastníctvom distribučnej siete $\mathrm{z}$ dôvodu vysokej investičnej náročnosti výstavby [3]. Prirodzenou vlastnost'ou je existencia len jednej prípojky pre odberné miesto. Z ekonomického pohl'adu nie je efektívne, aby každý trhový subjekt budoval samostatnú distribučnú siet alebo prípojku na dodávku energií. Pre uvedené postavenie podnikov na trhu je potrebná existencia trhového mechanizmu z dôvodu vyrovnávania dopytu a ponuky, ktorá je nahrádzaná externými zásahmi - regulátorom. Uvedenými vonkajšími zásahmi sú nastavené pravidlá, ktoré zabraňujú zneužívaniu monopolného postavenia na trhu [4].

Základný rámec regulácie v siet'ových odvetviach vymedzuje regulačná politika, ktorú vypracúva Rada pre reguláciu. Uplatnenie metód regulácie na základe regulačných nástrojov sú priorizované a využívané podl'a určenej stratégie na dosiahnutie ciel'ov regulačného 
obdobia [5, 6]. Využitie metód a regulačných nástrojov má byt' transparentné, cielené a nediskriminačné. Predpokladom pre správne fungovanie regulácie je zavedenie kontrolných mechanizmov pre sledovanie a dodržiavanie pravidiel hospodárskej sút’aže z pohl'adu využívania dominantného postavenia na trhu. Významný prvkom je taktiež ochrana práv spotrebitel'ov.

Regulačná politika je strategickým dokumentom, ktorý ustanovuje východiská, princípy a spôsoby regulácie siet'ových odvetví pre vymedzené regulačné obdobie. Obsahom regulačnej politiky v oblasti teplárenstva je výroba, distribúcia, dodávka tepla a elektrickej energie a s tým súvisiace služby alebo činnosti [7].

Regulačná politika stanovuje postupy Rady pre reguláciu a Úradu pre reguláciu siet'ových odvetví v nadväznosti na právne predpisy [8]. Regulačná politika legislatívnou formou určuje rozmer regulácie na nasledujúce regulačné obdobie. Základné členenie priameho alebo nepriameho vplyvu regulátora môžeme definovat' v oblastiach:

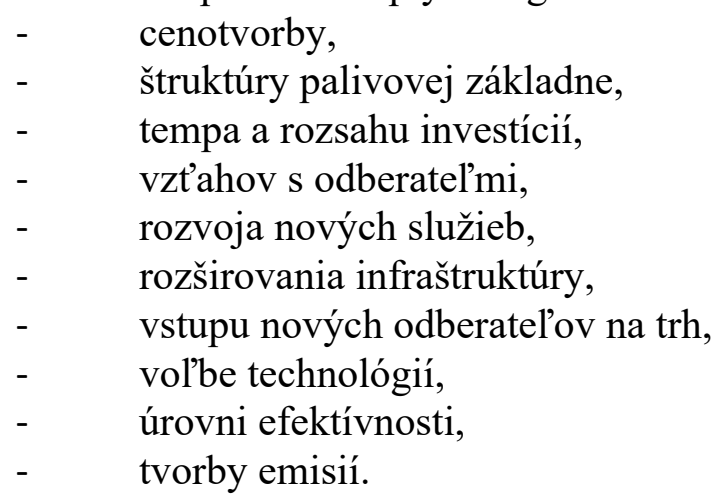

Tepelná energia má oproti ostatným produktom energetiky, ako sú elektrická energia alebo plyn, určitú odlišnost'. V porovnaní trhových štruktúr sú komodity ako elektrina a plyn na trhu dostupné od rôznych dodávatel'ov/obchodníkov. Dostupnost' tepelnej energie je zvyčajne zabezpečovaná jedným dodávatel'om. Umiestnenie firiem na trhu z teplom má charakter prirodzeného monopolu $\mathrm{z}$ dôvodu vlastníctva distribučných sietí jednou spoločnost'ou, ktorá dodáva teplo a zároveň je aj jeho výrobcom. To čo majú tieto komodity spoločné, je práve existencia jednej distribučnej siete, ktorá je viazaná na transportovaný druh komodity. V takomto prípade môžeme hovorit' o segregácií firiem, ktoré delíme na dodávatel'ské/obchodné spoločnosti a distribučné spoločnosti. Z pohl'adu vysokých nákladov na prevádzku distribučnej siete a jej výstavbu je prirodzená práve existencia jedného vlastníka, často s väčšinovým zastúpením štátu. Oproti teplu je elektrina a plyn dopravovaná na väčšie vzdialenosti medzi siet’ami, $\mathrm{v}$ rámci krajiny aj medzi krajinami. Zmenou dodávatel'a plynu a elektriny nie je dotknutý iný odberatel' týchto energií v porovnaní $\mathrm{s}$ dodávkou tepla, ktorá počíta $\mathrm{s}$ rozložením nákladov na straty pri distribúcií tepla ako aj samotnú výrobu tepla.

Na rozdiel od dodávky plynu a elektrickej energie je dodávka tepla význačná tým, že miesto výroby je v čo najkratšej vzdialenosti k miestu spotreby a vzdialenost' transportu tepelnej energie je zvyčajne $\mathrm{v}$ desiatkach kilometrov. Tepelná energia teda nie je obchodovatel'ná medzi jednotlivými krajinami a vnútornými siet’ami práve z pohl'adu špecifickej charakteristiky distribúcie tepelnej energie. Distribúcia tepla je príznačná vysokými stratami v súvislosti s charakteristikou prepravného média, dížkou distribučnej siete a kvalitou prepravného potrubia.

O spôsobe zásobovania teplom pre danú lokalitu rozhoduje samospráva. V rámci SR podl'a zákona č. 657/2004 Z.z. o tepelnej energetike [9] je povinnost'ou obce nad 2500 obyvatel'ov zabezpečit' koncepciu rozvoja obce v oblasti tepelnej energetiky [11]. V oblasti výstavby energetických stavieb vydáva obec záväzné stanovisko o súlade navrhovanej výstavby sústavy tepelných zariadení s celkovým inštalovaným tepelným výkonom do 10 
MW. Oblast' výstavby energetických stavieb musí byt' v súlade s koncepciou rozvoja obce v oblasti tepelnej energetiky $[11,12]$.

S výrobou tepla úzko súvisí aj výroba elektrickej energie, čo je príznačné práve pre teplárenstvo. Kombinovaná výroba tepla a elektrickej energie (KVET) vzniká expanziou pary alebo iných plynov, pričom čast' energie je premenená pomocou mechanickej energie roztáčaním generátora na elektrickú energiu a zvyšná čast' energie je dodávaná do distribučnej siete na pre uspokojenie potreby tepla. Využitie súbežnej výroby tepla a elektrickej energie je v súčasnosti najefektívnejší spôsob zabezpečenia dopytu po teple a elektrickej energie.

Zásobovanie obyvatel'stva teplom je vykonávane systémom :

- Centralizované zásobovanie teplom (CZT) ktorého súčast’ou sú teplárne, výhrevne, kotolne zásobujúce teplom viac ako jeden objekt.

- Decentralizované zásobovanie teplom (DZT) ktorého súčast’ou sú individuálne domové kotolne, tepelné zdroje pre firmy.

- Kombinácia oboch systémov zásobovania teplom.

Elektrická energie je vykonávaná systémom:

- Dodávka do nadradenej distribučnej siete nízkeho napätia, vysokého napätia a vel'mi vysokého napätia. Vlastníkom distribučnej siete nie je dodávatel' alebo výrobca elektrickej energie.

- Pomocou miestnej distribučnej siete MDS nízkeho napätia, vysokého napätia. Vlastníkom distribučnej siete je dodávatel' alebo výrobca elektrickej energie.

- Kombinácia oboch systémov dodávky elektrickej energie.

\section{Produkčná krivka v teplárenstve}

Pre aplikáciu produkčnej funkcie $v$ teplárenstve je potrebné definovat' vyrábaný produkt umiestnený na trhu, ako aj vstupy potrebné pre jeho produkciu.

V súčasnosti teplárenstvo sleduje zvyčajne dve hlavné produktové línie, a to produkciu tepla a elektrickej energie. Hlavnou dopytovanou zložkou je teplo pre komunálne potreby a technologické procesy, ktoré bolo tiež dominantným produktom subjektov na trhu teplárenstva. Produkcia elektrickej energie však umožňuje týmto subjektom riešit' sezónne výkyvy v technologických procesoch.

Komunálna spotreba tepla je priamo závislá od vonkajších poveternostných vplyvov a technických charakteristík vykurovaných objektov. Tie svojou skladbou plášt'a a využitím technických konštrukčných prvkov ovplyvňujú straty tepla, ktoré sú nahrádzané vykurovacím teplom.

V teplárenstve je dominantná výroba tepla využitím kombinovanej a vysoko účinnej kombinovanej výroby tepla a elektrickej energie. Produkcia elektrickej energie je priamo závislá od úrovne dopytu po dodaní tepla. Množstvo vyrobenej elektrickej energie môžeme vyjadrit' vo vzt'ahu:

Kde:

$$
\mathrm{E}=\mathrm{Q} * \mathrm{C}_{\mathrm{ACTUAL}}
$$

E - výroba elektrickej energie

$\mathrm{Q}$ - výroba tepla

$\mathrm{C}_{\mathrm{ACTUAL}}-\mathrm{je}$ pomer vyrobenej elektriny $\mathrm{k}$ teplu 


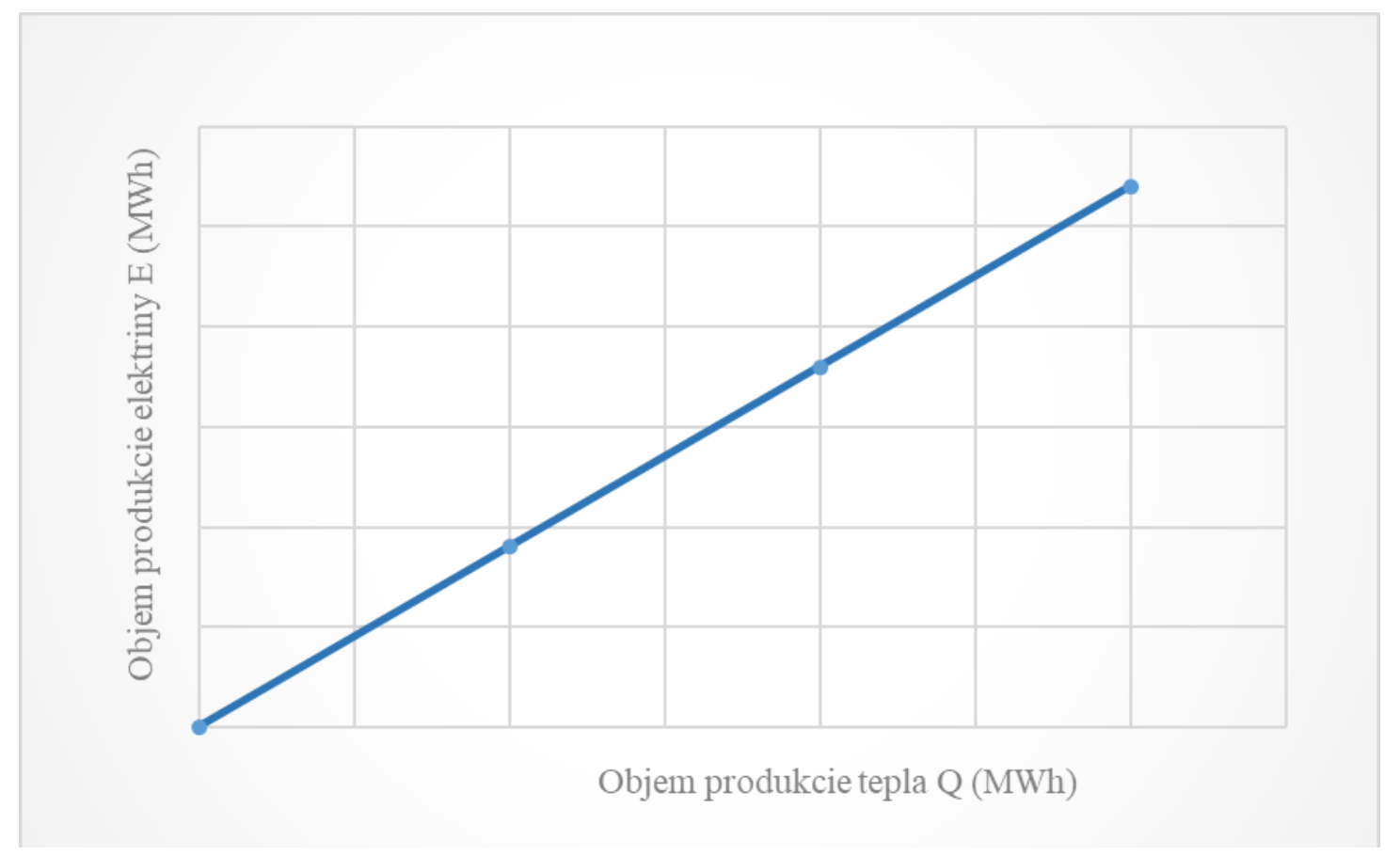

Obr. 1 Závislost' výroby elektriny od dodaného tepla

Pre zjednodušenie budeme $\mathrm{v}$ tomto prípade uvažovat' o lineárnom vzt'ahu, kde $\mathrm{C}_{\mathrm{ACtUAL}}$ je koeficient výroby, je uvedený pomer definovaný krivkou účinnosti, ktorej charakter vyplýva z druhu a samotného nastavenia použitej technológie.

Celkové príjmy sú v tomto prípade výsledkom vynásobenia jednotkovej ceny a množstva dodaného tepla a elektriny.

Pre stanovenie celkových nákladov TC sú identifikované vstupy potrebné na výrobu tepla a elektrickej energie, ktorými sú palivo, práca a ostatné vychádzajúce z riadenia a prevádzky technológie. Vzt’ah paliva a práce je striktne komplementárny.

Využitie práce ako vstupu je skokové. To znamená, že pre výrobu 1 až $50 \mathrm{MW}$, ked' hovoríme priamo iba o riadiacom personáli, je potrebný beh 2 strojov, ktoré zabezpečuje obsluha v počte $C_{1}$. Pre výrobu väčšieho množstva energie ako $50 \mathrm{MW}$ je potrebný beh d'alších strojov, čo vyžaduje d'alšiu obsluhu v počte $C_{2}$ pre zvýšenie výkonového rozsahu. Uvedená situácia je znázornená na obrázku 2. 


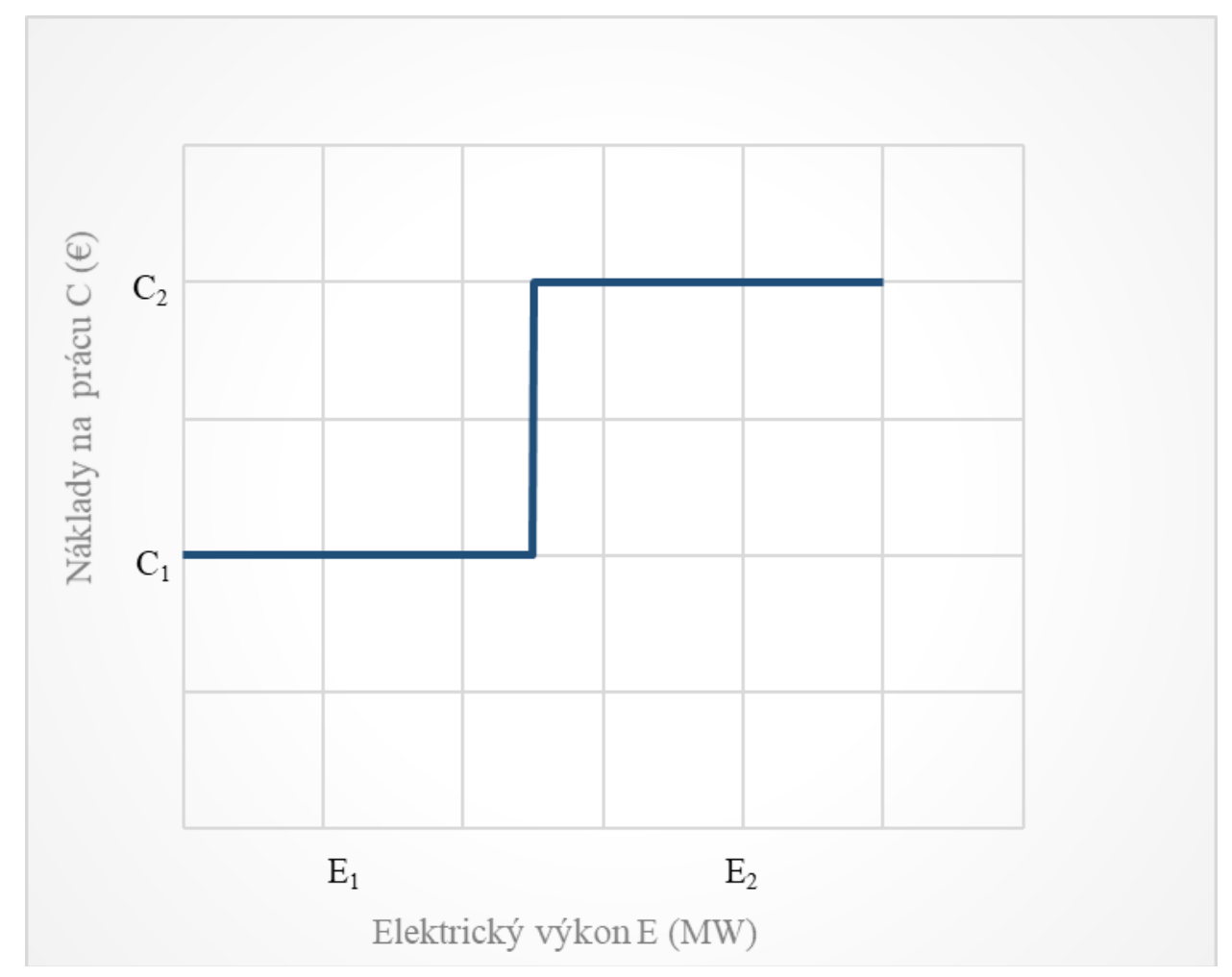

Obr.2 Práca podl’a výkonového rozsahu

Ked’že ide o prácu, ktorá je úzko špecifikovaná z pohl’adu firmy, ktorá zamestnáva vysoko kvalifikovaný personál na riadenie technológie, je fixný náklad C započítaný počas celého obdobia nezávisle od aktuálneho objemu produkcie. $Z$ tohto pohl'adu sú náklady na prácu lineárne a platí:

$$
\mathrm{C}=\left(\mathrm{C}_{1}+\mathrm{C}_{2} \ldots+\mathrm{C}_{\mathrm{N}}\right)
$$

Využitie inputov pre produkciu je delený medzi výrobu tepla a výrobu elektrickej energie, kde čast' paliva je využívaná na produkciu tepla a čast' na produkciu elektrickej energie. Všeobecne platí:

$$
\mathrm{M}_{\mathrm{pal}}=\mathrm{M}_{\mathrm{pal}} \mathrm{Q}+\mathrm{M}_{\mathrm{pal}} \mathrm{E}
$$

$\mathrm{M}_{\mathrm{pal}}$ - celková spotreba paliva

$\mathrm{M}_{\text {pal_}} \mathrm{Q}$ - spotreba paliva na výrobu tepla

$\mathrm{M}_{\text {pal_E }}$ - spotreba paliva na výrobu elektriny

Obdobne môžu byt' delené všetky náklady podl’a výstupu produkcie.

Spotreba paliva je rozdelená pomerom využitia paliva Mpal na výrobu tepla vyjadrená koeficientom $\mathrm{B}_{\mathrm{q}}$.

$$
\mathrm{B}_{\mathrm{q}}=\mathrm{Q} / \mathrm{M}_{\mathrm{pal}}
$$

$\mathrm{B}_{\mathrm{q}}$ - koeficient spotreby tepla $\mathrm{v}$ palive na výrobu tepla

$\mathrm{M}_{\mathrm{pal}}$ - celková spotreba paliva

$\mathrm{Q}$ - množstvo dodaného tepla 
Pre určenie spotreby paliva na výrobu elektrickej energie použijeme pomerový koeficient $\mathrm{B}_{\mathrm{e}}$. Z uvedeného vyplýva:

$$
\mathrm{B}_{\mathrm{e}}=1-\mathrm{B}_{\mathrm{q}}
$$

Delenie spotreby paliva na výrobu tepla a elektrickej energie je nasledovná:

$$
\begin{aligned}
& \mathrm{M}_{\mathrm{pal} \_} \mathrm{Q}=\mathrm{B}_{\mathrm{q}} * \mathrm{M}_{\mathrm{pal}} \\
& \mathrm{M}_{\mathrm{pal} \_\mathrm{E}}=\mathrm{B}_{\mathrm{e}} * \mathrm{M}_{\mathrm{pal}}
\end{aligned}
$$

V takomto nastavení, by hl'adanie optimálneho bodu produkcie s ohl'adom na dosiahnutie maximálneho zisku $\mathrm{Q}_{\mathrm{E}}$ bolo bezpredmetné, ked’že zisk by neustále rástol $\mathrm{s}$ nárastom produkcie.

V reálnom prostredí je nárast nákladov na produkciu nelineárny. V teplárenstve sú výrobné náklady [10] delené medzi tieto hlavné nákladové položky:

- spotreba paliva

- spotreba elektrickej energie (nákup elektriny, poplatky za prevádzkovanie systému a systémové služby)

- poplatky za (emisie, spotrebu vôd, aditív, olejov a náplní)

- náklady na opravy

- spotrebné dane

Jednotlivé nákladové položky sú d’alej štruktúrované na d’alšie časti. Príkladom je spotreba paliva, konkrétne zemného plynu. Pri prepočte spotreby zemného plynu na obrázku 3 vidiet' vplyv vývoja nákladov na $\mathrm{m}^{3}$, kde pri zvyšovaní spotreby jeho cena klesá a pri znižovaní spotreby rastie.

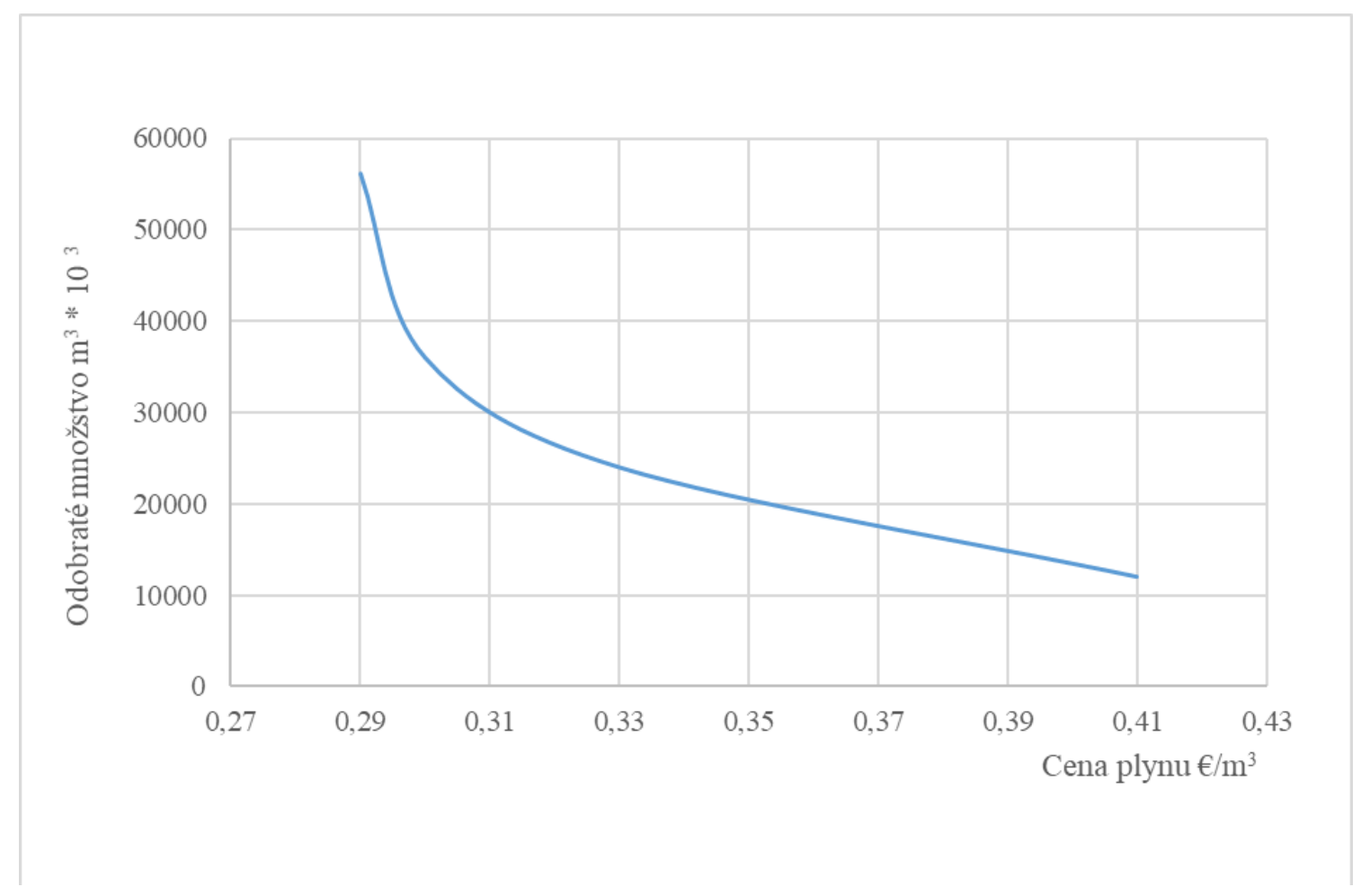

Obr.3 Závislost' ceny a spotrebovaného objemu plynu pri cene za komoditu 23,0 €/MWh 
Náklady na palivo sú vyjadrené fixnou, ako aj variabilnou zložkou ceny, ktoré majú vplyv na cenu paliva.

\section{Záver}

Ked' berieme do úvahy reálnu závislost' medzi nákladmi a samotným objemom výroby, hl'adanie optimálneho bodu produkcie má z tohto pohl'adu význam. Avšak je potrebné dodat', že dodávka a spotreba tepla je striktne závislá na vonkajších podmienkach, t.j. počasí. Firma teda nevie priamo ovplyvnit' svoj objem produkcie tepla. Môže však ovplyvnit' produkciu elektrickej energie a to práve radením druhu technológie s rôznou účinnost'ou (technologickou charakteristikou do prevádzky). Ked’že skladba technologických zariadení je variantná, a aj súvisiace náklady s ich využitím majú priamy vplyv na zisk firmy.

Najväčší problém teplárenských spoločností vyplýva $\mathrm{z}$ ich vel'kosti v nadväznosti na vysoké investičné náklady na technológie. Využitie produkčnej funkcie má z tohto pohl’adu význam pre dlhodobé plánovanie obnovy a technologickej modernizácie.

\section{Literatúra}

[1] LISÝ, J. A KOL.: Ekonómia, Wolters Kluwer, Praha 2016, ISBN 978-80-7552-275-7

[2] SCHILLER, B.R.: Mikroekonómia. Computer press, ISBN 80-251-0169-x

[3] ETZIONI, A.: The Capture Theory of Regulations-Revisited. Society. 2009, 46. 319323. DOI: $10.1007 / \mathrm{s} 12115-009-9228-3$

[4] FENDEKOVÁ,E., FENDEK, M.: Mikroekonómia, oligopoly a regulované monopoly, Wolters Kluwer, s.r.o. , 2018, ISBN 978-80-816-766-2

[5] LISÝ, J. A KOL.: Dejiny ekonomických teórií, Bratislava 2018, ISBN 979-80-7598-0809

[6] VESELKOVÁ, A. A KOL.: Mikroekonómia, Sprint 2 s.r.o. Bratislava 2017, ISBN 97880-89-710-34-8

[7] Zákon č 250/2012 o regulácii v siet’ových odvetviach. Dostupný na https://www.slovlex.sk/pravne-predpisy/SK/ZZ/2012/250/20210101

[8] DEN HERTOG, J.: General theories of regulation. Part of Encyclopedia of Law and Economics, s. 223 - 270, Economic Institute/CLAV, Utrecht University (C) Copyright 1999 Johan den Hertog. Dostupné na http://dspace.library.uu.nl/handle/1874/19806

[9] Zákona č. 657/2004 Z.z. o tepelnej energetike. Dostupný na https://www.slovlex.sk/pravne-predpisy/SK/ZZ/2004/657/20210101

[10]ÚRSO SR: Cenové rozhodnutia 2017-2021. Dostupné na https://www.urso.gov.sk/cenove-rozhodnutia-2017-2021/

[11]MH SR: Integrovaný národný energetický a klimatický plán na roky 2021 - 2030 spracovaný podl'a nariadenia EP A RADY (EÚ) Č. 2018/1999 o riadení energetickej únie a opatrení v oblasti klímy. Bratislava. Október 2019, Dostupné na https://www.mhsr.sk/uploads/files/zsrwr58v.pdf

[12]Európsky parlament, Rada Európskej únie: Nariadenie Európskeho parlamentu a Rady (EÚ) 2018/1999 z 11. decembra 2018 o riadení energetickej únie a opatrení v oblasti klímy, ktorým sa menia nariadenia Európskeho parlamentu a Rady (ES) č. 663/2009 a (ES) č. 715/2009, smernice Európskeho parlamentu a Rady 94/22/ES, 98/70/ES, 2009/31/ES, 2009/73/ES, 2010/31/EÚ, 2012/27/EÚ a 2013/30/EÚ, smernice Rady 2009/119/ES a (EÚ) 2015/652 a ktorým sa zrušuje nariadenie Európskeho parlamentu a Rady (EÚ) č. 525/2013 (Text s významom pre EHP). PE/55/2018/REV/1, Aktuálne 
konsolidované znenie: 01/01/2021 Celexové číslo: 32018R1999. Dostupné na https://eurlex.europa.eu/homepage.html?locale $=$ sk

\section{Grantová podpora}

Táto publikácia vznikla vd'aka podpore projektu VEGA 1/0011/21 Výskum interakcií medzi novými emergentnými technológiami, výkonnost'ou podnikov a odvetví založených na sietovej technologickej infraštruktúre, uplatňovaním nových business modelov a inštitucionálnym regulačným, environmentálnym a sociálnym prostredím 